\title{
Tissue Engineered Strategies for Pseudoarthrosis
}

\author{
Umile Giuseppe Longo ${ }^{*}, 1,2$, Ugo Trovato ${ }^{1,2}$, Mattia Loppini ${ }^{1,2}$, Giacomo Rizzello ${ }^{1,2}$, \\ Wasim Sardar $\mathrm{Khan}^{3}$, Nicola Maffulli ${ }^{4}$ and Vincenzo Denaro ${ }^{1,2}$
}

\author{
${ }^{I}$ Department of Orthopaedic and Trauma Surgery. Campus Bio-Medico University, Via Alvaro del Portillo, 200, 00128 \\ Trigoria, Rome, Italy \\ ${ }^{2}$ Centro Integrato di Ricerca (CIR) Campus Bio-Medico University, Via Alvaro del Portillo, 21, 00128, Rome, Italy \\ ${ }^{3}$ University College London Institute of Orthopaedics and Musculoskeletal Sciences, Royal National Orthopaedic \\ Hospital, Stanmore, London, HA7 4LP, UK \\ ${ }^{4}$ Centre for Sports and Exercise Medicine, Barts and The London School of Medicine and Dentistry, Mile End Hospital, \\ 275 Bancroft Road, London, E1 4DG, UK
}

\begin{abstract}
Numerous classification systems of non-union have been proposed based on: presence or absence of infection, radiographic features, clinical findings, biologic activity, location and shape. The management of pseudarthrosis is strongly related to the type of non-union (infected versus uninfected, atrophic versus hypertrophic). Surgical management of pseudarthrosis is generally effective with a success rate ranging from 75 to $100 \%$. Nevertheless, in a relatively high number of instances several combined treatments are required for the fracture healing. The current gold standard to stimulate the bone regeneration is represented by the revision surgery with the application of autologous bone grafts. However, several approaches have been described to promote and enhance the bone tissue regeneration, including extracorporeal shock wave therapy (ESWT), ultrasound, electromagnetic, bone morphogenic proteins (BMPs) and platelet-rich-plasma (PRP).

The aim of the present study was to perform a systematic review of the literature evaluating the current therapies to promote and enhance the bone tissue healing. The systematic review was performed according to PRISMA guidelines with a PRISMA checklist and algorithm.

Limitations of the present systematic review are mainly related to the scanty quality of the studies available in the literature. Although the therapies previously described for the management of patients with non-unions seems to be effective, the limitations of the included studies, especially the extensive clinical heterogeneity, make not possible to provide clear recommendations regarding the application of these approaches. The problems remain the need to better understand the most effective treatment options, subject to surgical stabilization as a first step.
\end{abstract}

Keywords: Biologic stimulation, bone regeneration, electromagnetic, non-union, pseudoarthrosis, ultrasound.

\section{INTRODUCTION}

The term of pseudarthrosis or non-union is usually applied to fractures which do not consolidate within a period between 6 and 8 months [1]. On the other hand, the term of delayed union indicates fractures which consolidate in a period longer than normal [2] Both conditions are characterized by specific clinical and radiological signs.

Numerous classification systems of non-union have been proposed based on: presence or absence of infection, radiographic features, clinical findings, biologic activity, location and shape. The AO classification includes: hypertrophic non-union, consisting of a false joint where a

*Address correspondence to this author at the Department of Orthopaedic and Trauma Surgery, Campus Bio-Medico University, Via Alvaro del Portillo, 200, 00128 Trigoria, Rome, Italy; Centro Integrato di Ricerca (CIR) Campus Bio-Medico University, Via Alvaro del Portillo, 21, 00128, Rome, Italy; Tel: + 39062254 11; Fax: + 3906 225411934;

E-mail: g.longo@unicampus.it fibrocartilaginous cavity is lined with synovium producing synovial fluid; avascular/avital non-union with or without bone loss, resulting from injury and/or surgery which lead to devascularization of the bone fragments; atrophic non-union, which is a vascularized non-union secondary to marked instability resulting in resorption of bone fragment and rounding of their ends.

The management of pseudarthrosis is strongly related to the type of non-union (infected versus uninfected, atrophic versus hypertrophic) $[3,4]$. The intramedullary nailing is usually preferred for an uninfected non-union of long bone shaft. On the other hand, the external fixation is indicated in patients with an infected non-union of long bone shaft. In patients with closed non-unions, the management with compression plates has been also investigated [5-8]. In case of hypertrophic non-unions, high success rates have been reported with compression plates alone, whereas supplementary bone-grafting seems to be required for atrophic non-unions. Finally, the Ilizarov technique has been 
used for the management of angulated malunions and failures of union associated with malalignment.

Surgical management of pseudarthrosis is generally effective with a success rate ranging from 75 to $100 \%$ [915]. Nevertheless, in a relatively high number of instances several combined treatments are required for the fracture healing. The current gold standard to stimulate the bone regeneration is represented by the revision surgery with the application of autologous bone grafts, usually from the iliac crest, with or without replacement of the fracture fixation 0 [16]. However, several approaches have been described to promote and enhance the bone tissue regeneration, including extracorporeal shock wave therapy (ESWT), ultrasound, electromagnetic, bone morphogenic proteins (BMPs) and platelet-rich-plasma (PRP).

The aim of the present study was to perform a systematic review of the literature evaluating the current therapies to promote and enhance the bone tissue healing. The feasibility and the effectiveness of these were also assessed.

\section{MATERIALS AND METHODS}

\section{Electronic Literature Search}

The systematic review was performed according to PRISMA (Preferred Reporting Items for Systematic Reviews and Meta-analyses) guidelines with a PRISMA checklist and algorithm $[17,18]$, and already validated in our setting [1936]. Three independent reviewers (UGL, UT, and ML) separately conducted the search. All journals were considered, and all relevant articles were analyzed. Only articles published in a peer-reviewed journal were included. All articles were initially screened for relevance by title and abstract, excluding articles without an abstract, and obtaining full-text article if the abstract did not allow the authors to assess the defined inclusion and exclusion criteria. The three authors (UGL, UT, and ML) reviewed the abstract of each publication, than performed a close reading of all papers and extracted data, to minimize selection bias and errors. A cross reference research of the selected articles was also performed to obtain other relevant articles for the study.

The search was performed on 1st April 2012. The following databases were screened: Medline, Google Scholar, EMBASE and Ovid. All articles reporting outcomes on tissue engineered strategies, performed singularly or in combination with other surgical procedures, for the management of non-unions have been included. Given the linguistic capabilities of the authors, articles in English, French, Spanish, German or Italian were included. According to the Oxford centre of EBM, level I, II, III, IV articles were found in the literature and included in our study. Literature reviews, case reports, studies on animals, cadavers or in vitro, biomechanical reports, tumoral studies, technical notes, letters to editors and instructional course were excluded.

Finally, to avoid bias, the selected articles, the relative list of references and the articles excluded from the study were reviewed, assessed and discussed by all the authors and if there was disagreement among authors regarding inclusion and exclusion criteria the senior authors (NM and VD) made the final decision.
The inclusion and exclusion criteria for study analysis, the check-list and the search algorithm according to PRISMA guidelines are respectively given in Tables $\mathbf{1}$ and $\mathbf{2}$ and Fig. (1).

\section{RESULTS}

The literature search and cross-referencing resulted in a total of 3422 references of which 2100 were rejected due to off topic abstract and/or failure to respect inclusion criteria (Fig. 1).

After reading the remaining full text articles, another 1270 were excluded because of insufficient details and uncertain diagnosis and outcomes measures. The remaining 52 articles, describing a total of 1411 non-union in 1410 patients, were included in the study.

\section{Extracorporeal Shock Wave Therapy}

Three of the included studies investigated ESWT [3739], including 325 patients ( 230 males and 95 females) with an average age of 41.7 years at the time of treatment. Patients were evaluated at an average follow-up of 12 months. ESWT was effective in 249 of 325 (77\%) patients. On the other hands, there was a failure in $59(18 \%)$ patients and unknown result in $17(5 \%)$. In the included studies, no major adverse side effects were recorded in association with the ESWT or the subsequent period of immobilization.

\section{Ultrasound}

Four studies evaluating the ultrasound therapy were taken into account [40-43]. The total number of patients undergoing ultrasound was 104 (71 males and 33 females) with an average age of 38.48 years at the time of treatment. This approach resulted effective in $70(67 \%)$ patients. There was a failure in $3(3 \%)$ patients and unknown result in 17 $(16 \%)$. No treatment-related complications were reported in these studies.

\section{Electromagnetic}

Ten studies investigating electromagnetic were taken into account, including 329 patients [44-53] (172 males, 67 females and 90 with unknown gender) with an average age of 36.93 years at the time of treatment, ranging from 32 to 46 years. Patients were assessed at an average follow-up of 9.8 months (ranged from 12 weeks to 120 months). In five studies, including 178 patients, the management consisted in a combination of surgery and electromagnetic. This approach resulted successful in $134(77 \%)$ patients and uneffective in $44(23 \%)$. In the remaining five studies, a comparison between electromagnetic alone and electromagnetic associated with surgery has been performed. The association of these treatments resulted in better results than electromagnetic approach alone (success rate $75 \%$ - 57 of 76 patients - versus $43 \%$ - 32 of 75 patients - and failure rate $25 \%$ - 19 of 76 patients - versus $57 \%$ - 43 of 75 patients).

\section{Bone Morphogenic Proteins}

Ten studies investigated BMPs [10, 54-61], including 630 patients ( 369 males, 178 females, and 83 with unknown gender) with an average age of 50.06 years at the time of treatment, ranging from 35.3 to 56.6 years. Patients were assessed at an average follow-up of 18.45 months (ranged from 12 to 29.2 months). 
Table 1. PRISMA Check List

\begin{tabular}{|c|c|c|c|}
\hline Section/Topic & $\#$ & Checklist Item & $\begin{array}{l}\text { Reported } \\
\text { on Page \# }\end{array}$ \\
\hline \multicolumn{3}{|l|}{ TITLE } & \\
\hline Title & 1 & Identify the report as a systematic review, meta-analysis, or both. & \\
\hline \multicolumn{3}{|l|}{ ABSTRACT } & \\
\hline Structured summary & 2 & $\begin{array}{l}\text { Provide a structured summary including, as applicable: background; objectives; data sources; study eligibility } \\
\text { criteria, participants, and interventions; study appraisal and synthesis methods; results; limitations; } \\
\text { conclusions and implications of key findings; systematic review registration number. }\end{array}$ & \\
\hline \multicolumn{3}{|l|}{ INTRODUCTION } & \\
\hline Rationale & 3 & Describe the rationale for the review in the context of what is already known. & \\
\hline Objectives & 4 & $\begin{array}{l}\text { Provide an explicit statement of questions being addressed with reference to participants, interventions, } \\
\text { comparisons, outcomes, and study design. }\end{array}$ & \\
\hline \multicolumn{3}{|l|}{ METHODS } & \\
\hline $\begin{array}{l}\text { Protocol and } \\
\text { registration }\end{array}$ & 5 & $\begin{array}{l}\text { Indicate if a review protocol exists, if and where it can be accessed (e.g., Web address), and, if available, } \\
\text { provide registration information including registration number. }\end{array}$ & \\
\hline Eligibility criteria & 6 & $\begin{array}{l}\text { Specify study characteristics (e.g., PICOS, length of follow-up) and report characteristics (e.g., years } \\
\text { considered, language, publication status) used as criteria for eligibility, giving rationale. }\end{array}$ & \\
\hline Information sources & 7 & $\begin{array}{l}\text { Describe all information sources (e.g., databases with dates of coverage, contact with study authors to identify } \\
\text { additional studies) in the search and date last searched. }\end{array}$ & \\
\hline Search & 8 & $\begin{array}{l}\text { Present full electronic search strategy for at least one database, including any limits used, such that it could be } \\
\text { repeated. }\end{array}$ & \\
\hline Study selection & 9 & $\begin{array}{l}\text { State the process for selecting studies (i.e., screening, eligibility, included in systematic review, and, if } \\
\text { applicable, included in the meta-analysis). }\end{array}$ & \\
\hline $\begin{array}{l}\text { Data collection } \\
\text { process }\end{array}$ & 10 & $\begin{array}{l}\text { Describe method of data extraction from reports (e.g., piloted forms, independently, in duplicate) and any } \\
\text { processes for obtaining and confirming data from investigators. }\end{array}$ & \\
\hline Data items & 11 & $\begin{array}{l}\text { List and define all variables for which data were sought (e.g., PICOS, funding sources) and any assumptions } \\
\text { and simplifications made. }\end{array}$ & \\
\hline $\begin{array}{l}\text { Risk of bias in } \\
\text { individual studies }\end{array}$ & 12 & $\begin{array}{l}\text { Describe methods used for assessing risk of bias of individual studies (including specification of whether this } \\
\text { was done at the study or outcome level), and how this information is to be used in any data synthesis. }\end{array}$ & \\
\hline Summary measures & 13 & State the principal summary measures (e.g., risk ratio, difference in means). & \\
\hline Synthesis of results & 14 & $\begin{array}{l}\text { Describe the methods of handling data and combining results of studies, if done, including measures of } \\
\text { consistency }\left(\mathrm{e} . \mathrm{g} ., \mathrm{I}^{2}\right) \text { for each meta-analysis. }\end{array}$ & \\
\hline $\begin{array}{l}\text { Risk of bias across } \\
\text { studies }\end{array}$ & 15 & $\begin{array}{l}\text { Specify any assessment of risk of bias that may affect the cumulative evidence (e.g., publication bias, } \\
\text { selective reporting within studies). }\end{array}$ & \\
\hline Additional analyses & 16 & $\begin{array}{l}\text { Describe methods of additional analyses (e.g., sensitivity or subgroup analyses, meta-regression), if done, } \\
\text { indicating which were pre-specified. }\end{array}$ & \\
\hline \multicolumn{3}{|l|}{ RESULTS } & \\
\hline Study selection & 17 & $\begin{array}{l}\text { Give numbers of studies screened, assessed for eligibility, and included in the review, with reasons for } \\
\text { exclusions at each stage, ideally with a flow diagram. }\end{array}$ & \\
\hline Study characteristics & 18 & $\begin{array}{l}\text { For each study, present characteristics for which data were extracted (e.g., study size, PICOS, follow-up } \\
\text { period) and provide the citations. }\end{array}$ & \\
\hline $\begin{array}{l}\text { Risk of bias within } \\
\text { studies }\end{array}$ & 19 & Present data on risk of bias of each study and, if available, any outcome level assessment (see item 12). & \\
\hline $\begin{array}{l}\text { Results of individual } \\
\text { studies }\end{array}$ & 20 & $\begin{array}{l}\text { For all outcomes considered (benefits or harms), present, for each study: (a) simple summary data for each } \\
\text { intervention group (b) effect estimates and confidence intervals, ideally with a forest plot. }\end{array}$ & \\
\hline Synthesis of results & 21 & Present results of each meta-analysis done, including confidence intervals and measures of consistency. & \\
\hline $\begin{array}{l}\text { Risk of bias across } \\
\text { studies }\end{array}$ & 22 & Present results of any assessment of risk of bias across studies (see Item 15). & \\
\hline Additional analysis & 23 & $\begin{array}{l}\text { Give results of additional analyses, if done (e.g., sensitivity or subgroup analyses, meta-regression [see Item } \\
\text { 16]). }\end{array}$ & \\
\hline
\end{tabular}


(Table 1) contd.....

\begin{tabular}{|c|c|c|c|}
\hline Section/Topic & $\#$ & Checklist Item & $\begin{array}{l}\text { Reported } \\
\text { on Page \# }\end{array}$ \\
\hline \multicolumn{4}{|l|}{ DISCUSSION } \\
\hline $\begin{array}{l}\text { Summary of } \\
\text { evidence }\end{array}$ & 24 & $\begin{array}{l}\text { Summarize the main findings including the strength of evidence for each main outcome; consider their } \\
\text { relevance to key groups (e.g., healthcare providers, users, and policy makers). }\end{array}$ & \\
\hline Limitations & 25 & $\begin{array}{l}\text { Discuss limitations at study and outcome level (e.g., risk of bias), and at review-level (e.g., incomplete } \\
\text { retrieval of identified research, reporting bias). }\end{array}$ & \\
\hline Conclusions & 26 & $\begin{array}{l}\text { Provide a general interpretation of the results in the context of other evidence, and implications for future } \\
\text { research. }\end{array}$ & \\
\hline \multicolumn{4}{|l|}{ FUNDING } \\
\hline Funding & 27 & $\begin{array}{l}\text { Describe sources of funding for the systematic review and other support (e.g., supply of data); role of funders } \\
\text { for the systematic review. }\end{array}$ & \\
\hline
\end{tabular}

Table 2. Inclusion and Exclusion Criteria

\begin{tabular}{|c|c|}
\hline INCLUSION CRITERIA & \\
\hline DATABASES & $\begin{array}{l}\text { Medline, Google Scholar, } \\
\text { EMBASE, Ovid }\end{array}$ \\
\hline SOURCH DATE/PUBDATE & $1^{\text {st }}$ April 2012/1982-2011 \\
\hline ARTICLE'S LENGUAGE & $\begin{array}{l}\text { English, French, Spanish, } \\
\text { German, Italian }\end{array}$ \\
\hline LEVEL OF EVIDENCE & $\begin{array}{l}\text { Oxford centre of EBM, level I, } \\
\text { II, III, IV }\end{array}$ \\
\hline DIAGNOSIS & Non-unions results of fractures \\
\hline LESION ASSESSMENT & $\begin{array}{l}\text { Imaging: MRI, TC } \\
\text { Surgical: Open }\end{array}$ \\
\hline TYPE OF SURGERY & $\begin{array}{l}\text { stabilization of the fracture, } \\
\text { debridement and application of } \\
\text { tissue engineered }\end{array}$ \\
\hline OUTCOMES ASSESSMENT & $\begin{array}{l}\text { Clinical: Clinical examination } \\
\text { Imaging: MRI, TC evaluation }\end{array}$ \\
\hline MINIMUM FOLLOW-UP TIME & 6 months \\
\hline EXCLUSION CRITERIA & $\begin{array}{l}\text { Literature reviews, case reports, } \\
\text { studies on animals, cadavers or } \\
\text { in vitro, biomechanical reports, } \\
\text { tumoral studies, technical notes, } \\
\text { letters to editors and } \\
\text { instructional course }\end{array}$ \\
\hline TYPE OF STUDY & $\begin{array}{l}\text { All articles reporting outcomes } \\
\text { on tissue engineered strategies, } \\
\text { performed singularly or in } \\
\text { combination with other surgical } \\
\text { procedures, for the management } \\
\text { of non-unions. }\end{array}$ \\
\hline OUTCOMES MESURES & $\begin{array}{l}\text { no information on diagnosis, } \\
\text { follow up, imaging of the non- } \\
\text { unions, clinical examination, } \\
\text { clinical post operative } \\
\text { outcomes, statistical analysis of } \\
\text { the relative outcomes. }\end{array}$ \\
\hline
\end{tabular}

In five studies assessing the use of BMPs alone for the management of nonunion, the success rate was $88 \%-259$ of 294 patients - and failure rate was $12 \%$ - 35 of 294 patients. Three studies performed a comparison between BMPs alone and BMPs associated with autologus bone graft. The BMPs alone resulted in better results than the association of these treatments (success rate $87 \%$ - 71 of 82 patients - versus $58 \%-63$ of 108 patients - and failure rate $13 \%$ - 11 of 82 patients - versus $10 \%$ - 11 of 108 patients). Two studies performed a comparison between BMPs alone and BMPs associated with PRP. The BMPs alone resulted in better results than the association of these treatments (success rate $96 \%$ - 73 of 76 patients - versus $67 \%$ - 49 of 73 patients and failure rate $12 \%$ - 9 of 76 patients - versus $33 \%-24$ of 73 patients).

\section{Platelet-Rich-Plasma}

Three studies evaluated the use of PRP for the management of non-union [56, 57,62], including 95 patients (38 males, 34 females and 23 with unknown gender) with an average age of 39 years at the time of treatment. Patients were assessed at an average follow-up of 13 months. One study investigated the use of PRP alone in 22 patients, reporting a success rate of $91 \%$ (20 of 22 patients) and a failure rate of $9 \%$ ( 2 of 22 patients). On the other hand, two studies showed that the use of PRP with BMPs provide worse outcomes than BMPs alone.

\section{DISCUSSION}

The current gold standard management of non-unions consists of revision surgery with the application of autologus bone grafts with or without replacement of the fracture fixation. However, in the last decades, several approaches have been described to promote the bone tissue regeneration, including extracorporeal shock wave therapy (ESWT), ultrasound, electromagnetic, bone morphogenic proteins (BMPs) and platelet-rich-plasma (PRP).

The BMPs are members of the transforming growth factor-beta (TGF-b) superfamily with a great osteoinductive potential. They induce a sequential cascade of events for chondro-osteogenesis during the bone formation and fracture healing process, including chemotaxis [63], proliferation of mesenchymal and osteoprogenitor cells [1], and their differentiation into a chondrogenic or osteogenic lineage [64, 65]. Currently, two of the 16 different BMP-homologous human molecules 28 have been used in several clinical trials and are commercially available $[66,67]$. RhBMP-7 or OP-1 received FDA approval for use in patients with recalcitrant long bone non-unions where autograft is unfeasible and alternative treatments have failed. The rhBMP- 2 has been approved for the acute treatment of open tibial fractures 


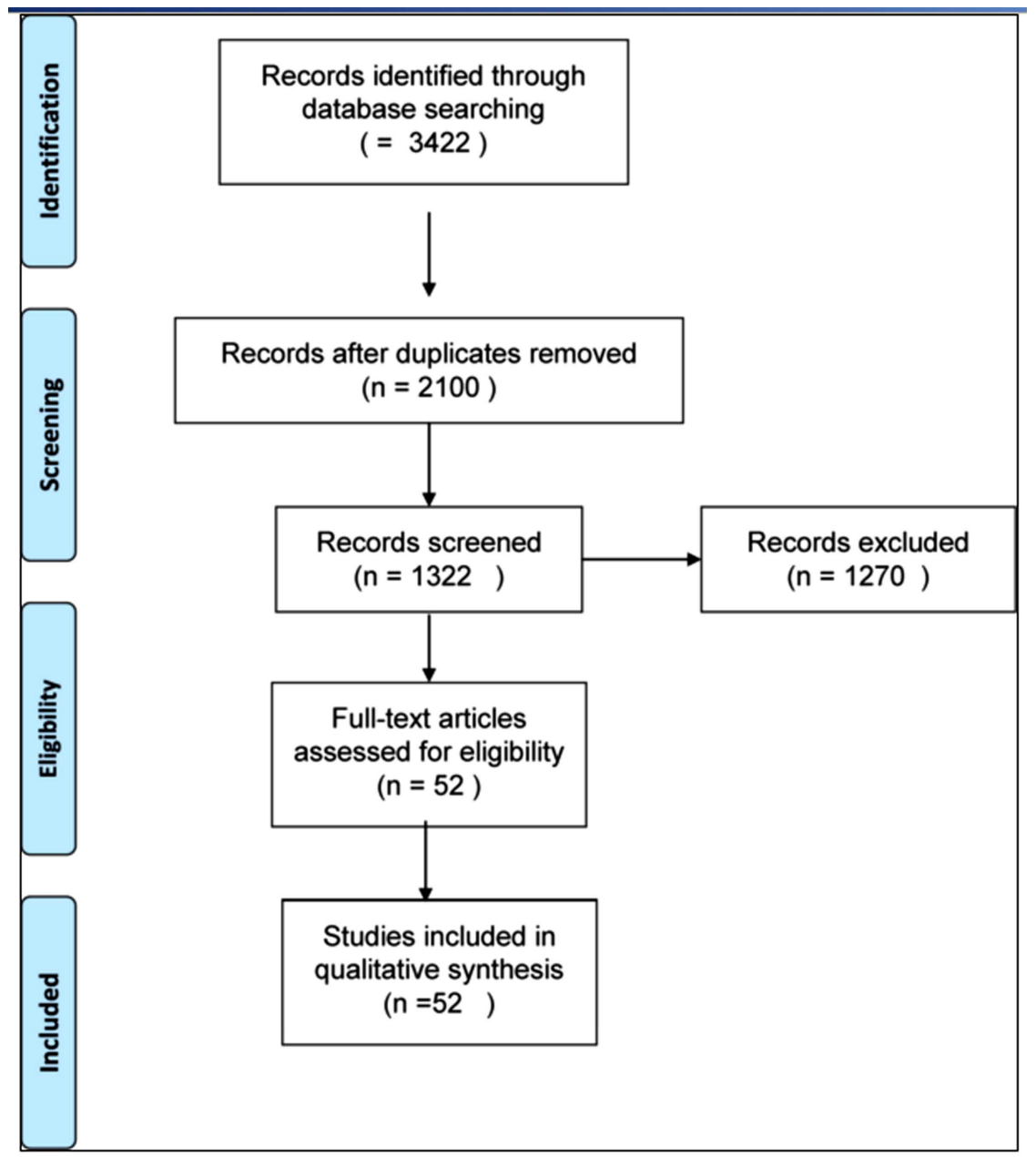

Fig. (1). PRISMA Flow diagram of the literature search.

associated with the intramedullary nail [68]. The results of the included studies confirm the efficacy of BMP-7 for the management of nonunion reporting a success rate around $88 \%$. Moreover, the effectiveness of the BMPs alone is greater than those of a combination of BMPs and PRP or BMPs and autologus bone graft. The BMP application can be associated with side effects, such as local erythema and swelling, heterotopic ossification and immune reactions. The use of BMP-7 is contraindicated in children and patients who are pregnant or have autoimmune deficiencies, or patients underwent immunosuppressive therapies.

The PRP application is related to the important role played by platelets in fracture healing. Indeed, the alpha granules of platelets, releasing several growth factors in the fracture rim, such as platelet-derived growth factor (PDGF), transforming growth factor beta (TGF-b), fibroblast growth factor (FGF-b), and vascular endothelial growth factor (VEGF) stimulate polymorphonuclear leukocytes, lymphocytes, monocytes, and macrophages [69]. TGF-b and PDGF molecules show in vivo osteoinductive capacity [70, 71]. Moreover, VEGF enhances bone formation and bone healing by improving angiogenesis [72], and appears to be an appropriate tool to induce bone healing in atrophic nonunions [73]. Among the three included studies evaluating the effectiveness of PRP, two assessed the combination of PRP with BMPs compared with the use of BMPs alone [3, 57].
Their findings suggest that the rhBMP-7 as a bonestimulating agent for the management of non-unions of the long bones is superior to the association of PRP and rhBMP7 with regard to their clinical and radiological efficacy.

The electromagnetic system consists in an electric current applied at the site of the fracture. The electromagnetic coils are applied over the fracture and are connected to the portable generator. The tension of the coils is set before starting treatment. During the treatment the fractured bone is immobilized. According to the results of the included studies, electromagnetic associated with surgery provide better results than electromagnetic approach alone (success rate $75 \%$ versus $43 \%$ ). Despite its good results, some authors do not recommend the use of electromagnetic stimulation as a first line treatment in unselected patients with delayed unions or non-unions, but suggest its application in patients that fail the conventional treatments.

ESWT can play a role in the management of non-union because they produce microfractures within the bone, stimulating neovascularization, osteoblast proliferation and activation, and synthesis of bone tissue. Delius et al. showed that shock waves produce radiographic lucencies in the bone marrow, intense formation of new cortical bone, and minor trabecular remodeling but did not cause gross fractures. ESWT is a safe and effective method for the treatment of delayed unions and pseudoarthrosis. In the included studies, 
the rate of success for the management of pseudoarthrosis was around $77 \%$. This approach should be taken into account in every case of bone union disturbances as, under favourable conditions, it may help to avoid surgery. Surgery should be performed whenever there is excessive displacement, high instability of bony fragments, and in the presence of bone defects.

Low intensity pulsed ultrasound (LIPUS) is a type of mechanical energy transmitted transcutaneously by highfrequency acoustic pressure waves. The intensity of LIPUS is within the range of ultrasound intensities used for diagnostic purposes and is regarded as non-thermal and nondestructie. Bone cells are sensitive to strains caused by physical loading. Mechanoreceptors convert biophysical stimuli into biochemical responses that modify gene expression and cellular adaptation. The micro-mechanical stress produced by LIPUS may provide a surrogate for the forces normally applied on bone by physical loading according to Wolffs' law. LIPUS increases prostaglandin E2 synthesis by the induction of cyclooxygenase- 2 in osteoblastic cells in vitro. Randomized clinical trials showed acceleration of clinical fracture healing by LIPUS in fresh fractures and osteotomies. LIPUS also restores the disrupted fracture healing process in non-union cases. The exact mechanism by which LIPUS affects clinical bone healing is however still unknown. The positive effect of LIPUS on fracture healing may be caused by a stimulation of the different cellular processes involved in fracture repair and bone formation, such as angiogenesis, chondrogenesis, and intramembranous and endochondral ossification.

Limitations of the present systematic review are mainly related to the scanty quality of the studies available in the literature. Moreover, as the data from the available studies were often poorly reported, it was not possible to perform a comprehensive pooling of data.

Although the therapies previously described for the management of patients with delayed and non-unions seems to be effective, the limitations of the included studies, especially the extensive clinical heterogeneity, make not possible to provide clear recommendations regarding the application of these approaches. The problems remain the need to better understand the most effective treatment options, subject to surgical stabilization as a first step. Clearly, studies of higher levels of evidence, including large randomised trials, should be conducted to help answer these questions. Future trials should use validated functional and clinical outcomes, adequate methodology, and be sufficiently powered.

\section{CONFLICT OF INTEREST}

The authors confirm that this article content has no conflict of interest.

\section{ACKNOWLEDGEMENTS}

Declared none.

\section{REFERENCE}

[1] Gerstenfeld LC, Cullinane DM, Barnes GL, Graves DT, Einhorn TA. Fracture healing as a post-natal developmental process: molecular, spatial, and temporal aspects of its regulation. J Cell Biochem 2003; 88: 873-84.
[2] Hernigou P, Beaujean F. Pseudarthrosis treated by percutaneous autologous bone marrow graft. Rev Chir Orthop Reparatrice Appar Mot 1997; 83: 495-504.

[3] Calori GM, Phillips M, Jeetle S, Tagliabue L, Giannoudis PV. Classification of non-union: need for a new scoring system? Injury 2008; 39 (Suppl 2): S59-63.

[4] Motsitsi NS. Management of infected nonunion of long bones: the last decade (1996-2006). Injury 2008; 39: 155-60.

[5] Müller ME. Treatment of nonunions by compression. Clin Orthop Relat Res 1965; 43: 83-92.

[6] Muller ME, Thomas RJ. Treatment of non-union in fractures of long bones. Clin Orthop Relat Res 1979: (138): 141-53.

[7] Rosen H. Compression treatment of long bone pseudarthroses. Clin Orthop Relat Res 1979; (138): 154-66.

[8] Weber BG, Brunner C. The treatment of nonunions without electrical stimulation. Clin Orthop Relat Res 1981; 161: 24-32.

[9] Babhulkar S, Pande K. Nonunion of the diaphysis of long bones. Clin Orthop Relat Res 2005; 431: 50-6.

[10] Dimitriou R, Dahabreh Z, Katsoulis E, Matthews SJ, Branfoot T, Giannoudis PV. Application of recombinant BMP-7 on persistent upper and lower limb non-unions. Injury 2005; 36 (Suppl 4): S51-9.

[11] Giannoudis PV, Tzioupis C. Clinical applications of BMP-7: the UK perspective. Injury 2005; 36 (Suppl 3): S47-50.

[12] Friedlaender GE, Perry CR, Cole JD, et al. Osteogenic protein-1 (bone morphogenetic protein-7) in the treatment of tibial nonunions. J Bone Joint Surg Am 2001; 83-A (Suppl 1): S151-8.

[13] Jones AL, Bucholz RW, Bosse MJ, et al. Recombinant human BMP-2 and allograft compared with autogenous bone graft for reconstruction of diaphyseal tibial fractures with cortical defects. A randomized, controlled trial. J Bone Joint Surg Am 2006; 88: 1431-41.

[14] Verbruggen JP, Stapert JW. Failure of reamed nailing in humeral nonunion: an analysis of 26 patients. Injury 2005; 36: 430-8.

[15] Wu CC, Chen WJ. A revised protocol for more clearly classifying a nonunion. J Orthop Surg 2000; 8: 45-52.

[16] Westerhuis RJ, van Bezooijen RL, Kloen P. Use of bone morphogenetic proteins in traumatology. Injury 2005; 36: 1405-12.

[17] Liberati A, Altman DG, Tetzlaff J, et al. The PRISMA statement for reporting systematic reviews and meta-analyses of studies that evaluate healthcare interventions: explanation and elaboration. BMJ 2009; 339: b2700.

[18] Moher D, Liberati A, Tetzlaff J, Altman DG, Group P. Preferred reporting items for systematic reviews and meta-analyses: the PRISMA statement. BMJ 2009; 339: b2535.

[19] De Mozzi P, Longo UG, Galanti G, Maffulli N. Bicuspid aortic valve: a literature review and its impact on sport activity. Br Med Bull 2008; 85 : 63-85.

[20] Khanna A, Friel M, Gougoulias N, Longo UG, Maffulli N. Prevention of adhesions in surgery of the flexor tendons of the hand: what is the evidence? Br Med Bull 2009; 90: 85-109.

[21] Khanna A, Gougoulias N, Longo UG, Maffulli N. Minimally invasive total knee arthroplasty: a systematic review. Orthop Clin North Am 2009; 40: 479-89, viii.

[22] Lippi G, Longo UG, Maffulli N. Genetics and sports. Br Med Bull 2010; 93: 27-47.

[23] Longo UG, Denaro L, Campi S, Maffulli N, Denaro V. Upper cervical spine injuries: indications and limits of the conservative management in Halo vest. A systematic review of efficacy and safety. Injury 2010; 41: 1127-35.

[24] Longo UG, Franceschetti E, Maffulli N, Denaro V. Hip arthroscopy: state of the art. Br Med Bull 2010; 96: 131-57.

[25] Longo UG, Franceschi F, Loppini M, Maffulli N, Denaro V. Rating systems for evaluation of the elbow. Br Med Bull 2008; 87: 131-61.

[26] Longo UG, King JB, Denaro V, Maffulli N. Double-bundle arthroscopic reconstruction of the anterior cruciate ligament: does the evidence add up? Journal Bone Joint Surg Br 2008; 90: 995-9.

[27] Longo UG, Loppini M, Denaro L, Maffulli N, Denaro V. Rating scales for low back pain. Br Med Bull 2010; 94: 81-144.

[28] Longo UG, Oliva F, Denaro V, Maffulli N. Oxygen species and overuse tendinopathy in athletes. Disabil Rehabil 2008; 30: 1563-71.

[29] Longo UG, Ronga M, Maffulli N. Acute ruptures of the achilles tendon. Sports Med Arth Rev 2009; 17: 127-38.

[30] Longo UG, Ronga M, Maffulli N. Achilles tendinopathy. Sports Med Arth Rev 2009; 17: 112-26.

[31] Maffulli N, Longo UG, Denaro V. Novel approaches for the management of tendinopathy. J Bone Joint Surg 2010; 92: 2604-13. 
[32] Maffulli N, Longo UG, Gougoulias N, Loppini M, Denaro V. Longterm health outcomes of youth sports injuries. Br J Sports Med 2010; 44: 21-5.

[33] Maffulli N, Longo UG, Hufner T, Denaro V. Surgical treatment for pain syndromes of the Achilles tendon. Der Unfallchirurg 2010; 113: 721-5.

[34] Maffulli N, Longo UG, Loppini M, Denaro V. Current treatment options for tendinopathy. Exp Opin Pharmacother 2010; 11: 2177-86.

[35] Maffulli N, Longo UG, Marinozzi A, Denaro V. Hallux valgus: effectiveness and safety of minimally invasive surgery. A systematic review. Br Med Bull 2011; 97: 149-67.

[36] Maffulli N, Longo UG, Spiezia F, Denaro V. Aetiology and prevention of injuries in elite young athletes. Med Sport Sci 2011; 56: 187-200.

[37] Bara T, Synder M. Nine-years experience with the use of shock waves for treatment of bone union disturbances. Ortop Traumatol Rehabil 2007; 9: 254-8.

[38] Elster EA, Stojadinovic A, Forsberg J, Shawen S, Andersen RC, Schaden W. Extracorporeal shock wave therapy for nonunion of the tibia. J Orthop Trauma 2010; 24: 133-41.

[39] Wang CJ, Chen HS, Chen CE, Yang KD. Treatment of nonunions of long bone fractures with shock waves. Clin Orthop Relat Res 2001; 2001: 95-101.

[40] Hemery X, Ohl X, Saddiki R, Barresi L, Dehoux E. Low-intensity pulsed ultrasound for non-union treatment: a 14-case series evaluation. Orthop Traumatol Surg Res 2011; 97: 51-7.

[41] Jingushi S, Mizuno K, Matsushita T, Itoman M. Low-intensity pulsed ultrasound treatment for postoperative delayed union or nonunion of long bone fractures. J Orthop Sci 2007; 12:35-41.

[42] Rutten MJ, Jager GJ, Kiemeney LA. Ultrasound detection of rotator cuff tears: observer agreement related to increasing experience. AJR Am J Roentgenol 2010; 195: W440-6.

[43] Uchiyama Y, Nakamura Y, Mochida J, Tamaki T. Effect of lowintensity pulsed ultrasound treatment for delayed and non-union stress fractures of the anterior mid-tibia in five athletes. Tokai J Exp Clin Med 2007; 32: 121-5.

[44] Lynch JR, Taitsman LA, Barei DP, Nork SE. Femoral nonunion: risk factors and treatment options. J Am Acad Orthop Surg 2008; 16: 88-97.

[45] Barker AT, Dixon RA, Sharrard WJ, Sutcliffe ML. Pulsed magnetic field therapy for tibial non-union. Interim results of a double-blind trial. Lancet 1984; 1: 994-6.

[46] Colson DJ, Browett JP, Fiddian NJ, Watson B. Treatment of delayedand non-union of fractures using pulsed electromagnetic fields. J Biomed Eng 1988; 10: 301-4.

[47] Scott G, King JB. A prospective, double-blind trial of electrical capacitive coupling in the treatment of non-union of long bones. J Bone Joint Surg Am 1994; 76: 820-6.

[48] Ito H, Shirai Y. The efficacy of ununited tibial fracture treatment using pulsing electromagnetic fields: relation to biological activity on nonunion bone ends. J Nihon Med Sch 2001; 68: 149-53.

[49] Freedman LS. Pulsating electromagnetic fields in the treatment of delayed and non-union of fractures: results from a district general hospital. Injury 1985; 16: 315-7.

[50] Meskens MW, Stuyck JA, Mulier JC. Treatment of delayed union and nonunion of the tibia by pulsed electromagnetic fields. A retrospective follow-up. Bull Hosp Jt Dis Orthop Inst 1988; 48: 170-5.

[51] Simonis RB, Parnell EJ, Ray PS, Peacock JL. Electrical treatment of tibial non-union: a prospective, randomised, double-blind trial. Injury 2003; 34: 357-62.

[52] Sharrard WJ, Sutcliffe ML, Robson MJ, Maceachern AG. The treatment of fibrous non-union of fractures by pulsing electromagnetic stimulation. J Bone Joint Surg Br 1982; 64: 189-93.

[53] Sharrard WJ. A double-blind trial of pulsed electromagnetic fields for delayed union of tibial fractures. J Bone Joint Surg Br 1990; 72: 347-55.
[54] Moghaddam A, Elleser C, Biglari B, Wentzensen A, Zimmermann G. Clinical application of BMP 7 in long bone non-unions. Arch Orthop Trauma Surg 2010; 130: 71-6.

[55] Bong MR, Capla EL, Egol KA, et al. Osteogenic protein-1 (bone morphogenic protein-7) combined with various adjuncts in the treatment of humeral diaphyseal nonunions. Bull Hosp Jt Dis 2005; 63: 20-3.

[56] Calori GM, Tagliabue L, Gala L, d'Imporzano M, Peretti G, Albisetti W. Application of rhBMP-7 and platelet-rich plasma in the treatment of long bone non-unions: a prospective randomised clinical study on 120 patients. Injury 2008; 39: 1391-402.

[57] Calori GM, D'Avino M, Tagliabue L, Albisetti W, d'Imporzano M, Peretti G. An ongoing research for evaluation of treatment with BMPs or AGFs in long bone non-union: protocol description and preliminary results. Injury 2006; 37 (Suppl 3): S43-50.

[58] Kanakaris NK, Calori GM, Verdonk R, et al. Application of BMP-7 to tibial non-unions: a 3-year multicenter experience. Injury 2008; 39 (Suppl 2): S83-90.

[59] Kanakaris NK, Lasanianos N, Calori GM, et al. Application of bone morphogenetic proteins to femoral non-unions: a 4-year multicentre experience. Injury 2009; 40 (Suppl 3): S54-61.

[60] Ronga M, Baldo F, Zappalà G, Cherubino P, Group B-IOSB. Recombinant human bone morphogenetic protein-7 for treatment of long bone non-union: an observational, retrospective, non-randomized study of 105 patients. Injury 2006; 37 (Suppl 3): S51-6.

[61] Zimmermann G, Wagner C, Schmeckenbecher K, Wentzensen A, Moghaddam A. Treatment of tibial shaft non-unions: bone morphogenetic proteins versus autologous bone graft. Injury 2009; 40 (Suppl 3): S50-3.

[62] Galasso O, Mariconda M, Romano G, et al. Expandable intramedullary nailing and platelet rich plasma to treat long bone non-unions. J Orthop Traumatol 2008; 9: 129-34.

[63] Wozney JM. Bone morphogenetic proteins. Prog Growth Factor Res 1989; 1:267-80.

[64] Giannoudis PV, Kanakaris NK, Einhorn TA. Interaction of bone morphogenetic proteins with cells of the osteoclast lineage: review of the existing evidence. Osteoporos Int 2007; 18: 1565-81.

[65] Sakou T. Bone morphogenetic proteins: from basic studies to clinical approaches. Bone 1998; 22: 591-603.

[66] De Biase P, Capanna R. Clinical applications of BMPs. Injury 2005; 36 (Suppl 3): S43-6.

[67] Szpalski M, Gunzburg R. Recombinant human bone morphogenetic protein-2: a novel osteoinductive alternative to autogenous bone graft? Acta Orthop Belg 2005; 71: 133-48.

[68] Mont MA, Ragland PS, Biggins B, et al. Use of bone morphogenetic proteins for musculoskeletal applications. An overview. J Bone Joint Surg Am 2004; 86-A (Suppl 2): 41-55.

[69] Schmitt JM, Hwang K, Winn SR, Hollinger JO. Bone morphogenetic proteins: an update on basic biology and clinical relevance. J Orthop Res 1999; 17: 269-78.

[70] Lamerigts NM, Buma P, Aspenberg P, Schreurs BW, Slooff TJ. Role of growth factors in the incorporation of unloaded bone allografts in the goat. Clin Orthop Relat Res 1999; (355 Suppl): 260-70.

[71] Bostrom MP, Asnis P. Transforming growth factor beta in fracture repair. Clin Orthop Relat Res 1998; (368): S124-31.

[72] Peng H, Usas A, Olshanski A, et al. VEGF improves, whereas sFlt1 inhibits, BMP2-induced bone formation and bone healing through modulation of angiogenesis. J Bone Miner Res 2005; 20: 2017-27.

[73] Geiger F, Bertram H, Berger I, et al. Vascular endothelial growth factor gene-activated matrix (VEGF165-GAM) enhances osteogenesis and angiogenesis in large segmental bone defects. J Bone Miner Res 2005; 20: 2028-35. 